\title{
Cultivation, Mining and Innovation of Rural Soft Power Resources
}

\author{
Li Wanjin \\ Tianjin Vocational Institute \\ Tianjin, 300402,China
}

\begin{abstract}
Rural soft power is the rural potential, tacit and ultimate core development force. Through the universal education of socialist core values, it can cultivate villages' innovation spirit soft power, improve innovation rural organization service function, and improve rural organization soft power. It can create different levels and different functions of rural cooperative organizations, mine rural development soft power source, cultivate rural feature culture, enrich rural cultural market and enhance rural cultural soft power. It can innovate skill training carrier, promote modern suitable science and technology, improve rural science and technology soft power, in order to improve rural soft environment from overall aspect, promoting rural economy society for leap development.
\end{abstract}

Keywords-rural soft power; human resource soft power; organization soft power; cultural soft power; education science and technology soft power;

\section{INTRODUCTION}

Rural soft power is rural potential, tacit and ultimate core development force, which has expansionary and conductivity, transcending the time and space, determining the rural sustainable development in the future. Rural soft power includes spirit soft power, organization soft power, cultural soft power and education science and technology soft power. In world resource shortage and global economic structure adjustment period, rural economic society overall development depends on soft power improvement. Cultivation, mining and innovating rural soft power are the core of solving "three rural" problems. Mining, cultivating and innovating rural soft power will greatly improve rural cohesion, creativity and development force, promoting rural economy society overall development and promoting rural modernization and overall constructing the smooth realization of wealthy goal.

\section{CULTIVATING, Mining AND INNOVATING RURAL HUMAN RESOURCE SOFT POWER}

Farmers are the most active and positive factor of promoting rural productivity. Without new concept, there will be no new farmers. Without new farmers, there will be no new countryside. Overall building well-off society and realizing agricultural modernization make us cultivate, mine and revitalize the rural human resources, enhancing rural cohesion and mining creativity and development.

\section{A. Cultivating Rural Innovation New Concept}

The focus of cultivating, mining and innovating rural human resource soft power is to cultivate reform and opening-up feature era concept. Socialis m market economy development makes farmers' material life change, and farmers' thinking pattern and values also have profound change.

\section{B. General Education Socialist Core Value System}

"Core value system is the soul of a country." In rural general education socialism core value, it uses govemment, academic circle, media and folk resources, leading farmers to establish socialism core values, focusing on villagers' moral quality education, democratic legal education, family virtue education, and the socialis $m$ core value system penetrating into farmers' life aspects, leading farmers to inherit rural folk songs, folk music, folk dance, folk stories, celebrity legend and folk stories, cultivating farmers' positive consciousness.

\section{Promoting the Rational Flow of Human Resources in Urban and Rural Areas}

It promotes the rational flow of human resources of urban and rural areas. On one hand, industrial development needs rural to provide high-quality labor. On the other hand, rural modernization, rural urbanization and rural overall well-off construction need a lot of high-quality organization management talents and a lot of high-end scientific and technological talents. Through market mechanism, revitalizing urban and rural human resources can promote human resource rational flow of urban and rural areas, in order to improve the talent mechanism.

\section{MINING, IMPROVING AND INNOVATING RURAL ORGANIZATION SOFT POWER}

Improving and innovating government and various rural organization functions and service modes can create various different types and different functions of rural associations, communities and organizations and other rural associations, in order to improve farmers to resist the market risk strength and play the community wisdom and team strength, and enhance rural organization soft power.

\section{A. Improving Innovation Rural Organization Soft Power}

Enhancing rural grassroots organization cohesion. Excellent party me mbers with reform and innovation spirit are selected into the organization team, enhancing the training of rural 
cadres, in order to make rural grass-roots cadres to establish open, pragmatic, honest image and improve the ability of transaction processing ability and improve the masses of rural economic development, villagers' autonomy organization, to strengthen the self management services, executing village affairs open, finance open and politics open; implementing villagers' democratic selection, democratic decision-making, democratic management and democratic supervision, benefiting by mutual discussion to improve the construction of rural areas.

\section{B. Constructing Excellent Politics and Law Environment}

Improving rural organization soft power, government and rural organization should eliminate the official standard, enhance service consciousness, eradicate corruption, creating loose political and legal environment, so that all sorts of talents show off themselves, activating and mobilizing rural cadres and masses to create work enthusiasm. We should strengthen political and legal environment, make up natural and economical environment shortage, to make excellent political and law environment into full play, in order to walk a high scientific content, good economic benefit, less resource consumption, less environment pollution and human resource advantage for full play in ecological civilization construction road.

\section{Cultivating Innovation Villager Community Function}

It can cultivate and innovate different types and styles of rural community organizations, in order to make different members in the same association organization learn from each other, collaborative business, and seek common development. It can establish scientific association, agricultural technical association, rural research association and other rural folk communities, and establish various rural planting associations and communities and various breeding as sociations and communities.

\section{MINING, IMPROVING AND INNOVATING RURAL CULTURAL SOFT POWER}

Culture is the national blood, which is human spiritual home. It follows "government-oriented, rural main body, social undertaking and market operation" development path, making advanced culture occupy rural market, healthy culture influence farmer masses, beneficial culture educate masses and farmer masses enjoy a happy life.

\section{A. Mining Cultural Products and Innovating Exchange Channels}

Rural cultural construction has the main resource in local area, and the position is in natural village. Various villages have difference in economic development level, cultural development degree, villager education degree and villager age, and they propose different levels of demands for cultural works creation, production and dissemination, enriching cultural product quality, grade, type, quantity and level, in order to meet various rural masses' demand and expand rural cultural demand.

\section{B. Mining Folk Customs and Cultivating Rural Culture}

We can respect farmers' master status, making all the culture creation source give full play, helping farmers to open activity places, establishing performance teams and organizing lion and dragon dance and team organization. Creating cultural market and realizing village culture yard, rural house and radio and television network coverage to every village, in order to make the common people enjoy the achievement of cultural industry's prosperous development.

\section{Mining Local Features and Innovating Cultural Industry}

China is an agricultural country and also agricultural civilized country. We can implement rural culture refined project and improve rural culture brand, creating rural celebrity brand, cultural tourism brand and sighting-seeing agricultural brands. It takes village town appearance as the breakthrough point, creating a happy environment, shaping a rural new image, using the excellent environ ment to improve rural quality, to make farmers feel new rural happiness, encouraging and stimulating farmers to construct new rural confidence, enthusiasm and energy, attracting citizens for leisure activities.

\section{MINING, IMPROVING AND INNOVATING RURAL EDUCATION SCIENCE AND TECHNOLOGY SOFT POWER}

Education is the foundation. Rural basic education, occupation education and adult education division form joint efforts and mutually cultivate new farmers, improving rural education scientific and technology soft power and improving rural comprehensive quality, which can cultivate billions of cultural, technical and operational new farmers for rural development, in order to increase the sustainable development force of rural economy society.

\section{A. Strengthening Compulsory Education and Strength from Childhood}

By establishing education and training system, creating cultural tutorial schools, literacy school, it can make rural labor continue to obtain learning opportunities after receiving school education, enhancing market concept and improving rural overall cultural level.

To play the rural knowledge youth leading role. Rural areas have a large number of high school cultural level of youth, who are willing to contribute to rural agricultural development. This is rural talent development new force, and they live in villages, and their thinking mode and production behavior have a good appeal and demonstration, fully cultivating and developing the people's talent, promoting their deeds, stimulating their internal motivation. 


\section{B. Developing Skill Training and Improving Villagers' Employability and Entrepreneurial Abilities}

Rural vocational technical education college layout, professional layout, teacher training can be comprehensively balanced according to rural industrial structure adjustment requirement, domestic international labor market demand and rural employment willingness. According to farmers' learning features, it adopts centralized training and individual learning combination, classroom teaching and production practice combination, remote education and actual guidance combination, full-time, part-time and full-time study and short-time training, depending on satellite $\mathrm{TV}$, computer network, China education satellite broadband network, promoting "sending teaching to the countryside", "flow class room vehicle" training new mode.

\section{Promoting Modern Adaptation Science and Technology and Improving Agricultural Production Efficiency}

Modern agricultural science and technology promotion and application should implement the specific work of farmers who are engaged in. Conducting "scientific, healthy and culture" three rural activities, organizing scientific and technology staff into agricultural production first line, teaching farmers to advanced production, processing and storage technology, guiding farmers for scientific production. In practice, exploring and using farmer entrepreneur and the promotion role of planting experts and they can summarize the experience of scientific and technology demonstration households to farmers. We can organize farmers for external investigation, watching and seeking for modern agricultural mode, enhancing scientific and technology to promote agriculture. We can encourage agricultural science and technology staff and farmers sign technology contract, using information network. Through comprehensive analysis, it can provide accurate demand information and modern agricultural technology information for farmers and provide paid service for farmers to make them know market and understand market, in order to conduct production with goals and plans. We advocate farmers to read a book, learn a technology and work as a new farmer.

\section{ACKNOWLEDGMENT}

Fund project: 2010 education department humanity social science research project, Project approval number: 10YJA710025

\section{REFERENCES}

[1] CPC Central Committee, the State Council on accelerating the development of modern agriculture to further enhance the vitality of rural development opinions.

[2] Hu Jintao, 18th National Congress Report of the Communist Party. 2012.11.8. Xinhuanet.com
[3] CPC Central Committee on deepening the reform of the cultural system to promote socialist cultural development and prosperity of certain major issue decision. 2011.10.18

[4] Education department on accelerating the development of rural vocational education opinion. www.moe.edu.cn. Teacher Vocational College[2011]13. 2011.10 .25$.

[5] 6th National population census data. Central Government Portal Website. www.gov.cn 2011.04.28. Source: National Statistics Bureau Website.

[6] Teng Lin. Soft power resource and Chinese culture construction strategy. Changjiang University Journal(Social and Science Edition)

[7] Li Huaimin, Constructing high-quality rural leader team[N]. Organization Personnel Report. 2012-11-01 (012)

[8] Cui Yangqiang, Wang Yupeng. Improving national cult ure soft power path[N]. Guangming Daily. 2012-12-16(007) 